\title{
Aspects of Legal Certainty, Justice and Usability in the Decisions of Judges in Civil Courts
}

\author{
Ichsanullah $^{1}$, Faisal Santiago ${ }^{2}$ \\ \{ichsanullahulla@gmail.com ${ }^{1}$, faisalsantiago@borobudur.ac.id $\left.{ }^{2}\right\}$ \\ Universitas Borobudur, Jakarta, Indonesia ${ }^{1,2}$
}

\begin{abstract}
Legal clarity, fairness, and efficiency should all be present in a judge's ruling in court. It is difficult to harmonize these three characteristics in its execution, particularly among legal certainty and justice, which are frequently at odds. The results of the study revealed that a judge's decisionmaking is not always based on a single premise. Judges' constraints, which tend to entail legal certainty, reach a stalemate when drafted rules fail to address existing issues. The emphasis on the idea of justice often implies taking into account the law that exists in society, which is made up of norms and unwritten legal obligations. Judges must accommodate all factors that exist in a society in the form of habits and spoken legal requirements in their legal reasons and considerations. It is more cost-effective to place greater focus on the notion of benefit.
\end{abstract}

Keywords: Legal Certainty; Justice; Usability; Civil Courts

\section{Introduction}

Legal development includes three main components, namely material (substance), institutional (structure) and legal culture (culture) [1]. Permitted development is carried out through legal reform while considering the plurality of the applicable legal order and the influence of globalisation [2]. Such conditions are an effort to increase certainty, awareness, service and law enforcement with the core of justice, truth, order and welfare, in the context of an increasingly orderly and orderly state administration [3]. Legal politics, as a policy direction for legal evolution, must be used as a benchmark to assess the outcomes of legal activity at this time [4]. Law enforcement is a major milestone in the state, and it is even classified as a separate branch of the legal system. Every conflict that may be addressed is a result of the existence of law enforcement, whether it is a dispute between fellow citizens, a dispute between people and the state, or a dispute between the state and foreign nations. Thus, law enforcement is an absolute requirement for efforts to create a peaceful and prosperous Indonesian state [5].

Conceptually, law enforcement's essence and meaning lie in harmonising the relationship of values outlined in the existing norms in society to maintain order. The process of law enforcement thus is the application of the rules that apply to the community [6]. Paying attention to the function of law enforcement is a good place to start. Understanding the fundamentals of excellent law enforcement is the most important factor to consider. Likewise, 
judges in realising law enforcement are characterised by justice, legal certainty, and benefit through the judiciary.

The judicial power is an autonomous authority that administers justice and upholds the rule of law. This is also stated in the Law on Judicial Power, which states that judicial authority is the power of an independent state to administer justice, uphold law, and judge based on Pancasila in order to execute the Republic of Indonesia's legal form. Legal facts generally indicate public distrust in judicial power [7]. One of the key reasons is that the judge's ruling does not represent the priority that justice seekers place on legal clarity, fairness, and benefits.

The condition of the judicial power still concerns, following what Kanter describes, "if you don't want to lose a buffalo to save a goat, don't take it to court." this country [8]. Judges strive to uphold truth and justice, and they must uphold the law consistently in their responsibilities. His life is not permitted to engage in behaviors that are contrary to honorable standards, and he must maintain a flawless personal conduct. According to Rosadi [9], however, the law requires morals, as in the imperial era (quid leges Leges sine moribus), what is a law if it is not accompanied by morality. Courts in the legal system have a huge obligation to the public to make decisions that represent legal clarity, fairness, and benefits, so that the judiciary can defend the community's goals and wants.

The judge, as one of the officials of the judicial power who carries out the judicial process, including the civil court process, of course, has a significant role in the decision's inception. Judges' decisions in court should ideally not generate new issues in the community, implying that the quality of judicial judgements has a significant impact on the community environment and impacts the court's authority and credibility. The fact is that many judges' choices in the legal process continue to stoke fresh debates and fail to address problems [10]. Though ideally, the judge's decision that was born should be able to resolve the case.

Judges ideally should be able to produce decisions that reflect legal certainty, justice and expediency. Judges' decisions that do not reflect legal certainty, justice and expediency ultimately affect the judiciary's image. Realising a judge's decision based on legal certainty, justice and practicality are not easy, especially the justice demands. There is because the concept of justice in the judge's decision is not easy to find benchmarks. Fair to one party, not necessarily felt the same by the other party. Based on the description above, the author is interested in bringing up this paper's Realising Legal Certainty, Justice and Benefit in Judge Decisions in Civil Courts.

\section{Methodology}

There is prescriptive legal study, or legal research, which seeks to discover methodologies, rules, or the should. The definition of rules, in this case, includes legal principles, legal rules, legal systems and concrete legal regulations, especially for all statutory instruments [9]. Following the object of the study, namely legal norms, this research is based on the availability of secondary legal materials. In this regard, Mertokusumo stated that field research could be complemented to improve the data (legal material) obtained from library research. According to Marzuki [11], Official documents in the form of all legal publications are known as legal materials. Legislation, Government Regulations, textbooks, law dictionaries, legal periodicals, and commentaries on court rulings are all examples of legal publications. The legal resources are then split into three categories: primary, secondary, and tertiary. Document studies, as well as collecting and analyzing judges' decisions from civil courts, are used to get secondary legal resources. 
Field study was conducted to supplement the legal materials. The information gathered is primary. Resource persons are chosen by directly selecting parties who are thought qualified to answer questions related to the study topic. Meanwhile, only individuals who have been directly associated with the subject under investigation are eligible to participate.

\section{Results and Discussion}

\subsection{Judge's Decision Reflecting Legal Certainty}

Judges have a responsibility to discover the right legislation while settling civil issues in court. Because the law may not govern it clearly and completely, it is not enough for the court to just look in the direction. Instead, the judge must investigate the legal ideals of society. Customary and unwritten law are the only legal values that exist in society. The digger is the judge, who formulates the information in a decision. The judge's ruling is part of the legal system's goal of achieving one of the legal truths or achieving legal certainty. The judge's ruling is the result of law enforcement based on legally significant (juridical) factors derived from the trial findings. The legal factors that judges utilize to make decisions are a determining factor in determining the quality of such judgements.

In order to achieve legal certainty, the judge's decision should be based on the following fundamental court objectives: first, providing a definitive solution, which means providing a way out of the legal problems that the parties (the Plaintiff and the Defendant) are facing; second, efficiency, which means that the process should be quick, simple, and low cost; third, following the purpose of the law that is used as the basis for the judge's decision; and fourth, following the purpose of the law that is used as the basis. Legal certainty, according to the judge's ruling, is a result based on the facts of the trial that are legally important and taken into account with conscience. Judges must always be able to understand the meaning of the laws and other rules that serve as the foundation for the application. The law must be used in accordance with the facts of the case so that the judge can create the case being tried as a whole, rationally and objectively.

The advancement of research in the realm of law will be aided by judges' rulings that incorporate aspects of legal certainty. This is because the judge's ruling, which has permanent legal effect, is no longer the view of the judge who determines the case, but rather the opinion of the court institution, which serves as a point of reference for the community in everyday interactions. It is required to examine one example of the South Jakarta District Court Judgment No. 1145/Pdt.G/2004/PN.Jak.Sel, namely the petition for Cancellation of Determination No. 61/Pdt.P/2004/PN.Jaksel, in order to understand the judge's decision that shows legal certainty. And the legal guardianship of children born out of wedlock.

Plaintiff is an Indonesian national, whereas the Defendant is an Australian national. At the same time, according to Thomson Medical Center's Birth Certificate No. S9526052G, Plaintiff and Defendant's connection has resulted in the birth of a son called Javier, who is 9 (nine) years old (Exhibit P 3). Around the end of December 2001, Plaintiff and Defendant ended their relationship. The kid is exclusively connected by blood to the mother, not the father, according to Indonesian affirmative law respecting children born out of marriage. Defendant had lodged an Application for Guardianship and simultaneously acknowledged the child through the Registrar's Office of the South Jakarta District Court without Plaintiff's knowledge, in which case the Defendant's conduct violated the appropriate legal laws. 
The panel of judges adjudicating this case gave legal considerations, the main points of which were as follows:

Whereas based on Certificate of Extract From Register Of the Births Republic Of Singapore No. S9526052G, Evidence T. 5/ P. 3 it has been proven that Plaintiff is indeed the biological mother of a child named Martin Javier Cooper, while Defendant is the child's father. That is based on the jurisprudence of MARI Reg. In one of its considerations, No. 3302K/Pdt/1996 dated May 28 1998, stated that the Central Jakarta District Court Decision dated October 25 1994, No. 539/Pdt.P/1994/PN. Jak. According to the Panel of Judges of the High Court, Pst, the cancellation should be requested at the Supreme Court of the Republic of Indonesia. Whereas the main point of Plaintiff's lawsuit is regarding the cancellation of the decision, which it considers to violate the law, the Panel of Judges believes that the lawsuit filed by Plaintiff is wrong because Plaintiff should have filed an appeal to the Supreme Court. Whereas based on the reasons mentioned above, Plaintiff's claim is declared inadmissible, and Plaintiff is stated that the losing party must be punished to pay the costs of this case.

The Panel of Judges who tried this case stated that Plaintiff's claim was unacceptable. Ordered Plaintiff to pay the court fees in the amount of Rp. 149.000,00 (one hundred and forty-nine thousand rupiahs. The judge's ruling in this case has aspects of fairness and advantage in it. The focus, on the other hand, is on legal clarity. Plaintiff simply questioned and wished to urge the panel of judges to overturn the decision of the South Jakarta District Court, therefore the elements of justice, particularly formal justice, were satisfied in this case. Meanwhile, the decision of the panel of judges, which fulfills the usefulness element in this case, is very beneficial for both parties because it is possible to know for sure who has the most right to the child with the conclusion of the board of judges regarding the guardianship status of the child. Furthermore, this ruling is beneficial to both parties and has implications for future case decisions.

According to the author's assessment, the judge's decision, in this case, is more inclined to the element of fulfilling legal certainty, This is not to say that it is unconcerned with justice and expediency. The three aspects of legal clarity, justice, and pragmatism were considered by the panel of judges in reaching their judgement. The focus, on the other hand, is on legal clarity. This may also be shown by looking at the purpose of Plaintiff's case, which is to have the Jak District Court ruling overturned. PN.JakSel. Cell No. 61/Pdt.P/2004. From this example, it can be concluded that legal certainty necessitates that the mechanism for enacting legal consequences be transparent and well-known to the general public. Legal certainty also necessitates the construction of the law in a sustainable and ethical manner.

\subsection{Judge's Decision Reflecting Justice}

It's tough to create standards for the disputing parties when it comes to the idea of a decision that is just. Fair for one side, but not always fair for the other. Judges must uphold justice.24 This follows the head of the decision, which reads: "For Justice Based on the One Godhead". In implementing the judge's conclusion reflecting justice, the author analyses one of the judges' decisions at the Tilamuta District Court No. 01/Pdt.G/2008/PN.TLM regarding unlawful acts of enjoying the results of disputed objects that have been traded.

Whereas Plaintiff owns a plot of land with 2 (two) hectares and 185 (one hundred and eighty-five) coconut trees growing on it, located in Tabongo Village, Dulupi District, Boalemo Regency. Then without Plaintiff's permission, in 2002 the Defendant began to take the coconut fruit that Plaintiff feels aggrieved by Defendant's actions. The judges think that Defendant is the legal owner of 185 (one hundred and eighty-five) coconut trees, based on the Sale and 
Purchase Letter dated January 24, 1997 (T.1). Thus, Defendant's act of controlling and enjoying the coconut fruit is not against the law as stipulated in 1365 of the Civil Code.

The panel of judges judged:

Dismissed Plaintiff's claim in its entirety. They state that 185 (one hundred and eightyfive) coconut trees in Tabongo Village, Dulupi District, Boalemo Regency, are the Defendant's legal property, obtained based on a sale and purchase on January 24, 1997sentenced the Plaintiff to pay court fees of Rp. 159.000, 00 (one hundred fifty-nine thousand rupiahs). According to the legal analysis, the result in this case represents an element of fairness since the panel of judges accepted the presence of equal rights and duties for all parties, and the board of judges ensured that existing regulations and the judge's decision were in compliance. This judge's ruling, according to the fairness demanded by society, allows the winning party to claim what is his right, while the loser fulfills his commitment.

This judge's judgment places a greater focus on the element of justice; yet, this does not negate the existence of legal certainty and benefits; parts of legal certainty and advantage are still there in the judge's decision. This ruling has offered a way out of legal concerns for all parties, therefore fulfilling the criterion of legal certainty. The judge's judgment was founded on the law, and litigants were given equal opportunity. Meanwhile, the utility of this judgement has resulted in satisfaction for the plaintiffs, the elimination of polemics or conflicts for the disputing parties, and the winning party's right has been restored.

Based on the case described above, in the context of finding and implementing justice, the judge's decision in court must be following its true purpose, namely: first, the judge's decision must carry out a definitive solution, which means providing a way out of the legal problems faced. Second, the judge's decision must be efficient, i.e., quick, simple, and low cost, because delayed justice is an injustice; third, the judge's decision must follow the purpose of the law on which the court's decision is based; fourth, the judge's decision must have aspects of stability, i.e., social order and public peace; and fifth, the judge's decision must have fairness, i.e., giving litigants equal opportunities. Fair implies placing everything in their proper position and giving everyone their due, which is founded on the premise that everyone is equal before the law (equality before the law). The emphasis on the idea of justice might entail taking into account the laws that exist in society, which include norms and unwritten legal obligations. When picking the concept of justice as the foundation for judging the issue at hand, judges must take into account all of the criteria that live in a community in the form of habits and oral legal circumstances.

\section{Conclusion}

When it comes to reviewing and judging cases, a judge isn't necessarily fixed on a single premise. On a case-by-case basis, the judge may decide to go in one path or the other. Judges must weigh legal factors for good reason, and in some cases must choose between the principles. The weight of the reasons and legal factors employed in the case may therefore be used to assess the soundness of the judge's decision. A judge can select when to be closer to legal certainty and when to be closer to justice by considering legal reasoning with solid cause. Between legal certainty and the point of justice, where the judge considers the law's purpose or use to the society, the concept of expediency is applied. In essence, the law exists to safeguard human rights. 
Judges are more likely to uphold written legal norms than existing favorable legislation because of the emphasis on legal certainty. For the sake of legal certainty, legislation is enforced. Judges who place a premium on legal certainty incur the risk of reaching a stalemate if the written provisions fail to address the issues at hand. In such a case, the court must find a way to close the legal loophole. Putting a greater focus on the notion of justice might imply taking into account the laws that exist in society, which include norms and unwritten legal obligations. Judges must accommodate all factors that exist in a society in the form of habits and spoken legal requirements in their legal reasons and considerations. It is more costeffective to place greater focus on the notion of benefit. The logic is that the law is for humans or a large group of individuals. As a result, the law's goal must be to benefit humanity or a large group of people.

\section{References}

[1] S. Mertokusumo, "Sistem Peradilan di Indonesia," J. Huk. IUS QUIA IUSTUM, vol. 6, no. 9, pp. 1-8, 2019, doi: 10.31219/osf.io/c7g3u.

[2] W. Sandholtz and M. R. Padalla, "Law and Politics in the Inter-American System: The Amnesty Cases," J. Law Court., no. Spring 2020, 2020.

[3] J. Burke, "Law, politics and intelligence: a life of Robert Hope," J. Policing, Intell. Count. Terror., vol. 15, no. 2, pp. 187-188, 2020, doi: 10.1080/18335330.2020.1775278.

[4] E. E. Supriyanto, "Revitalization of Pancasila as a Solution to The Problems Faced by The Indonesian Nation,” J. Pendidik. Nusant., vol. 1, no. 2, pp. 52-61, 2021.

[5] M. Žgur, "The law and politics of inclusion. From rights to practices of disidentification," Jurisprudence, vol. 12, no. 2, pp. 308-315, 2021, doi: 10.1080/20403313.2021.1874728.

[6] S. Hartono, "Perspektif Politik Hukum Nasional: Sebuah Pemikiran," in Hukum dan Pembangunan, 1983, pp. 465-480.

[7] E. Yudistira, M. Marsaid, and S. Rochmiyatun, "THE POLITICAL OF LAW TO THE GOVERNMENT POLICY ABOUT Political law in the country is the rule that makes the planning and development of national law in Indonesia . Achievement of legal development will encourage the achievement of legal objectives which i," Nurani, vol. 21, no. 1, pp. 13-24, 2021.

[8] F. Frenki, "Politik hukum dan perannya dalam pembangunan hukum di indonesia pasca reformasi," J. Asas, vol. 3, no. No 2 Juli 2011, pp. 1-8, 2011.

[9] O. Rosadi and A. Marwan, "Transformation of Legal Education in Indonesia Based on Social Justice," J. Polit. Law, vol. 13, no. 1, 2020.

[10] L. Kushonggo and F. Santiago, "Indonesian Legal Political Policy towards Determining Electricity Tariff in the Geothermal Industry," 2021, doi: 10.4108/eai.6-32021.2305977.

[11] D. Dewi and M. Barthos, "Juridical Analysis of Interpretation of Medical Negligence on the Legal Protection of Doctor,” 2021, doi: 10.4108/eai.6-3-2021.2306196. 